\title{
Bifunctional catalyst cracking gasification of vacuum residue for coproduction of light olefins and $\mathrm{H}_{2}$-rich syngas
}

\author{
Ruiyuan Tang ${ }^{1, a}$, Yuanyu Tian ${ }^{1,{ }^{*}}$, Yingyun Qiao ${ }^{1, c}$ \\ ${ }^{1}$ State Key Laboratory of Heavy Oil Processing, China University of Petroleum (East China), \\ Qingdao Shandong 266580, China \\ atangruiyuan86@126.com, *Corresponding author Email: btianyy1008@126.com, ${ }^{\text {c }}$ \\ qiao_yingyun@126.com@126.com
}

Keywords: bifunctional catalyst, vacuum residue, cracking, gasification, light olefins, syngas

\begin{abstract}
The residue cracking gasification process is intended to convert vacuum residue into light olefins by cracking and co-production the $\mathrm{H}_{2}$-rich syngas by gasifying the cracking-generated coke. In this paper, a bifunctional base catalyst is used and tested vacuum residue cracking gasification in a fluidized bed reactor in comparison with the effects over FCC catalyst and $\mathrm{SiO}_{2}$. The result shows that higher light olefins yield is produced with $\mathrm{Ca}_{12} \mathrm{Al}_{7}$ as the cracking catalyst in comparison with that over the FCC catalyst and $\mathrm{SiO}_{2}$. The coke over the $\mathrm{Ca}_{12} \mathrm{Al}_{7}$ catalyst is gasified well at $800{ }^{\circ} \mathrm{C}$ in steam. The content of $\mathrm{H}_{2}$ is about $55.5 \mathrm{vol} \%$ and with the content of $\mathrm{CH}_{4}$ is less than 0.2 vol\% when compared to 36.6 and 2.4 vol\% over the FCC catalyst, respectively.
\end{abstract}

\section{Introduction}

Heavy oil possesses a higher proportion and quality degradation in crude oil, which has been receiving more attention in the petrochemical industry. However, processing these above-mentioned feedstocks would inevitable produce petroleum residue a large amount. Thermal processing method for conversion these residues mainly include the hydrogenation [1], visbreaking [2], fluid catalytic cracking (RFCC) [3,4], coking (i.e., delayed coking, flexi-coking and fluid coking) [5,6]. In some condition, several conversion methods combinations are also possible [7]. Furthermore, hydrogen is important raw materials in the industrial production (i.e., synthesis ammonia, hydro-cracking and hydrogenation). At present, in the petroleum industry, hydrogen is produced mainly via separation from $\mathrm{H}_{2}$-rich off-gases (the dry gas and LPG) or naphtha catalytic reforming. The residues cracking gasification process is intended to convert petroleum residue into the products of light olefins, and also co-producing hydrogen via gasifying the cracking-generated coke.

In this study, a residues cracking gasification coupling process is used. For combination these two kinds of reactions, a dual fluidized bed system is used and the catalyst could alternately operate between the reactions of cracking and gasification. Hence, in this process, the catalyst could provide not only catalysis but also exothermic heat for the cracking reaction. Now, the zeolite catalyst has an adverse effect on reducing the coking formation [8,9], irrespective of whether a fresh catalyst or a hydrothermal treatment catalyst is used in the residues cracking process. Thus, this could increase both the operation cost and regeneration time in practical applications. Previous studies found that the base catalyst has advantages of high cracking stability, good hydrothermal properties, high light olefins yield and anti-coking property [10,11]. Furthermore, the base catalysts are widely applied in the reactions of transesterification to produce biodiesel [12] and the coke gasification because of its high reactivity, good production selectivity, and mild reaction conditions [13,14].

The aim of this study is to investigate the effects of bifunctional catalyst for both catalyzing the residue cracking and enhancing the coke gasification effects in a fluidized bed reactor. In this paper, three catalysts including calcium aluminate, $\mathrm{SiO}_{2}$ and commercial FCC are used to study the effects for the vacuum residue conversion.

\section{Experimental}

$\mathrm{CaCO}_{3}$ and $\mathrm{Al}_{2} \mathrm{O}_{3}$ were obtained from Tianjin Kemiou Chemical Reagent Co., Ltd. The FCC 
catalyst (hydrothermal treatment at $750{ }^{\circ} \mathrm{C} 6 \mathrm{~h}$ ) was supplied by Qingdao Huicheng Petrochemical Technology Co., Ltd. Vacuum residue is provided by the Shenghua refinery. The calcium aluminate catalyst is prepared via the solid-state synthesis method. In this preparation, $\mathrm{CaCO}_{3}$ and $\mathrm{Al}_{2} \mathrm{O}_{3}$ are mixed with a molar ratio of $12: 7$ and grinded in a mortar sufficiently for $3 \mathrm{~min}\left(3000 \mathrm{r} \cdot \mathrm{min}^{-1}\right)$. Then the catalyst is calcined at $1300{ }^{\circ} \mathrm{C}$ for $2 \mathrm{~h}$. Finally, the prepared base catalyst is deactivated by $100 \%$ steam at $750{ }^{\circ} \mathrm{C}$ for $6 \mathrm{~h}$ (heating rate $=10{ }^{\circ} \mathrm{C} \cdot \mathrm{min}^{-1}$ ) and denoted as the $\mathrm{Ca}_{12} \mathrm{Al}_{7}$ catalyst.

Vacuum residue cracking gasification process is conducted in a fluidized bed reaction device. For each device run, this reactor is first heated up to the needed temperature in the atmosphere of Ar. And also vacuum residue and water are preheated to about $90-100{ }^{\circ} \mathrm{C}$ and $120{ }^{\circ} \mathrm{C}$ separated. Steam is firstly introduced into the reactor to fluidize the catalyst particles. And then vacuum residue is fed into the reactor and mixed well in the preheated section. And the oil-steam mixture is atomized into tiny oil drop via a stainless steel distributor to contact well with the catalysts in the cracking section. The gaseous products are separated via an oil-gas separation system. The liquid products are cooled by a water-cooled tube to collect the heavier oil in the first collector, and the lighter oil is collected in the second collector with cooling water of $1{ }^{\circ} \mathrm{C}$. The non-condensable gas contents are measured by a wet gas meter and analysis by gas chromatography.

\section{Results and discussion}

\subsection{Vacuum residue catalytic cracking.}

Products distribution of vacuum residue cracking over three catalysts is exhibited in Table 1. In this section, a steam-to-oil ratio of 1.0 and catalyst-to-oil ratio of 7.0 are used to fluidize the catalyst particles and cracking vacuum residue.

Table 1 Products distribution of vacuum residue cracking over three catalysts

\begin{tabular}{ccccccc}
\hline Catalyst & \multicolumn{2}{c}{ Silica sand } & \multicolumn{2}{c}{ FCC } & \multicolumn{2}{c}{$\mathrm{Ca}_{12} \mathrm{Al}_{7}$} \\
\hline Temperature $/{ }^{\circ} \mathrm{C}$ & 600 & 650 & 600 & 650 & 650 & 700 \\
Gas yield /wt\% & 11.6 & 15.8 & 34.5 & 43.9 & 24.2 & 28.8 \\
C2-C3 olefinicity ${ }^{\mathrm{a}} \%$ & 25.8 & 29.2 & 32.8 & 37.6 & 52.3 & 55.1 \\
Coke yield /wt\% & 6.4 & 7.3 & 7.7 & 7.9 & 5.1 & 5.2 \\
Liquid yield /wt\% & 82.0 & 76.9 & 57.8 & 48.2 & 70.7 & 66.0 \\
Conversion/\% & 67.2 & 76.4 & 100 & 100 & 91.6 & 94.8 \\
Distillation distribution of cracking liquid & & & \\
Gasoline /wt\% & 8.7 & 16.2 & 53.4 & 57.3 & 46.5 & 52.6 \\
Diesel /wt\% & 14.1 & 20.8 & 42.6 & 40.1 & 29.8 & 30.2 \\
VGO /wt\% & 37.2 & 32.3 & 4.0 & 2.6 & 11.8 & 9.3 \\
Heavy oil /wt\% & 40.0 & 30.7 & 0 & 0 & 11.9 & 7.9
\end{tabular}

For silica sand, the cracking temperature increased from 600 to $650{ }^{\circ} \mathrm{C}$, the gas yield and the conversion of heavy oil is increased from $11.6 \mathrm{wt} \%$ and $67.2 \%$ to $15.8 \mathrm{wt} \%$ and $76.4 \%$, respectively. Furthermore, silica sand has lower olefinicity (about 28.0\%) and higher yields of coke and liquid. This might be because silica sand could not suppress the carbon deposited on its surface, and further facilitate the residue cracking and dehydrogenation effects. Furthermore, the yields of heavy oil and VGO are reduced from 40.0 and $37.2 \mathrm{wt} \%$ at $600{ }^{\circ} \mathrm{C}$ to 30.7 and $32.3 \mathrm{wt} \%$ at $650{ }^{\circ} \mathrm{C}$. The gasoline yield is increased from 8.7 to $16.2 \mathrm{wt} \%$, and the yield of diesel is increased from 14.1 to $20.8 \mathrm{wt} \%$. The FCC catalyst has a complete conversion of vacuum residue at $600{ }^{\circ} \mathrm{C}$ but caused about $30 \%$ of vacuum residue into the cracking gas and coke. The yields of gas and coke are increased to 43.9 and $7.9 \mathrm{wt} \%$ over the FCC catalyst. This is also implied that the FCC catalyst is adverse to decrease the coking formation. The liquid yield is about $48.2 \mathrm{wt} \%$ of gasoline and diesel fraction at $650{ }^{\circ} \mathrm{C}$.

For $\mathrm{Ca}_{12} \mathrm{Al}_{7}$ catalyst, all of the tested parameters (the heavy oil conversion, the yields of coke and gas) are reduced except that the liquid yield when compared to the FCC catalyst at $650{ }^{\circ} \mathrm{C}$. The 
C2-C3 olefinicity of $\mathrm{Ca}_{12} \mathrm{Al}_{7}$ catalyst is increased to above $52 \%$. This might be because the $\mathrm{Ca}_{12} \mathrm{Al}_{7}$ catalyst has lower hydrogen transfer and higher dehydrogenation effect. It is found that coke is from the condensation and dehydrogenation of resins and asphaltenes on the catalysts. The coke yield has changed little (about $5.2 \mathrm{wt} \%$ ), which is demonstrated that the $\mathrm{Ca}_{12} \mathrm{Al}_{7}$ catalyst can suppress carbon deposited. The liquid yield is about $66.0 \mathrm{wt} \%$ and above $85.0 \%$ of gasoline and diesel fraction.

Table 2 Composition of produced gas from gasifying coke

\begin{tabular}{ccccc}
\hline \multirow{2}{*}{ Catalyst } & \multicolumn{2}{c}{ Condition I } & \multicolumn{2}{c}{ Condition II } \\
\cline { 2 - 5 } & FCC & $\mathrm{Ca}_{12} \mathrm{Al}_{7}$ & FCC & $\mathrm{Ca}_{12} \mathrm{Al}$ \\
\hline $\mathrm{H}_{2} /$ vol\% & 41.2 & 61.7 & 36.6 & 56.0 \\
$\mathrm{CO} /$ vol\% & 43.4 & 14.5 & 43.7 & 12.2 \\
$\mathrm{CH}_{4} /$ vol\% & 3.1 & 0.2 & 2.4 & 0.1 \\
$\mathrm{CO}_{2} /$ vol\% & 11.3 & 23.0 & 16.5 & 31.0 \\
$\mathrm{C} 2-\mathrm{C} 3$ hydrocarbons $/$ vol\% & 1.0 & 0.6 & 0.8 & 0.6 \\
Coke conversion $/ \%$ & 82.6 & 90.7 & 90.8 & 97.5 \\
\hline
\end{tabular}

Condition I: pure steam at $800{ }^{\circ} \mathrm{C}$, Condition II: steam with 5 vol\%-oxygen at $800{ }^{\circ} \mathrm{C}$.

\subsection{Coke gasification.}

Table 2 shows the gas composition and the coke conversion with the FCC and $\mathrm{Ca}_{12} \mathrm{Al}_{7}$ catalyst. Condition I is conducted pure steam at $800{ }^{\circ} \mathrm{C}$, while Condition II involved steam-5 vol\% oxygen at $800{ }^{\circ} \mathrm{C}$. With respect to Condition I, the total $\mathrm{H}_{2}$ and $\mathrm{CO}_{2}$ content is about $84.0 \mathrm{vol} \%$ (with a $\mathrm{H}_{2}$ content of about 60.0 vol\%) over the $\mathrm{Ca}_{12} \mathrm{Al}_{7}$ catalyst. The gas composition over the FCC catalyst is shown a total $\mathrm{H}_{2}$ and $\mathrm{CO}$ content of $84.6 \mathrm{vol} \%$. And the content of $\mathrm{CO}_{2}$ reached $11.3 \mathrm{vol} \%$ and this represented an evidently reduce when compared to about 23.5 vol\% over the $\mathrm{Ca}_{12} \mathrm{Al}_{7}$ catalyst. This might be because the $\mathrm{Ca}_{12} \mathrm{Al}_{7}$ catalyst could enhance the water-gas shift reaction, and thus increase the content of $\mathrm{H}_{2}$ and $\mathrm{CO}_{2}$. The coke conversion is reached about $90.0 \%$ over the $\mathrm{Ca}_{12} \mathrm{Al}_{7}$ catalyst compared to $82.6 \%$ over the FCC catalyst. For Condition II, the content of $\mathrm{CO}_{2}$ over the $\mathrm{Ca}_{12} \mathrm{Al}_{7}$ catalyst is increased from 23.5 vol\% to 31.0 vol\%, whereas the $\mathrm{H}_{2}$ content of Condition I slightly reduced compared to that in Condition II due to partial combustion. The $\mathrm{CH}_{4}$ content is less than 0.2 vol\% over the $\mathrm{Ca}_{12} \mathrm{Al}_{7}$ catalyst compared to 2.4 vol\% over the FCC catalyst. Furthermore, the coke conversion is reached about $97.0 \%$ over the $\mathrm{Ca}_{12} \mathrm{Al}_{7}$ catalyst when compared to about $90.8 \%$ over the FCC catalyst, and this suggested the bifunctional characteristics of the $\mathrm{Ca}_{12} \mathrm{Al}_{7}$ catalyst.

\section{Summary}

Vacuum residue conversion is realized by the residue cracking gasification process. Particularly, the cracking produced the light products, and $\mathrm{H}_{2}$-rich syngas is coproduced via the coke gasification. It is found that the $\mathrm{Ca}_{12} \mathrm{Al}_{7}$ catalyst showed desired cracking activity for vacuum residue conversion at $700{ }^{\circ} \mathrm{C}$ with a catalyst-to-oil ratio of 7.0. The coke on the $\mathrm{Ca}_{12} \mathrm{Al}_{7}$ catalyst is about $5.2 \mathrm{wt} \%$ when compared to that of FCC catalyst and silica sand. The coke is gasified well over the $\mathrm{Ca}_{12} \mathrm{Al}_{7}$ catalyst by using the steam-5 vol\% oxygen at $800{ }^{\circ} \mathrm{C}$ with a $\mathrm{H}_{2}$ content of about 55.5 vol\% and virtually no $\mathrm{CH}_{4}$ (below 0.2 vol\%).

\section{References}

[1] S.K. Bej, Performance evaluation of hydroprocessing catalysts: a review of experimental techniques. Energy Fuels. Vol.16 (2002) No. 3, p. 774-84.

[2] J.B. Joshi, A.B. Pandit, K.L. Kataria, et al. Petroleum residue upgradation via visbreaking: a review. Ind. Eng. Chem. Res. Vol. 47 (2008) No. 23, p. 8960-88. 
[3] H. Mizutani, Y. Korai, I. Mochida, Behavior of sulfur species present in atmospheric residue in fluid catalytic cracking. Fuel. Vol. 86 (2007) p. 2898-2905.

[4] X. Dupain, M. Makkee, J.A. Moulijn, Optimal conditions in fluid catalytic cracking: A mechanistic approach. Appl. Catal. A. Vol. 297 (2006) No. 2, p. 198-219.

[5] A.J. Guo, X.J. Zhang, Z.X. Wang Simulated delayed coking characteristics of petroleum residues and fractions by thermogravimetry. Fuel Process. Technol. Vol. 89 (2008) No. 7, p. 643-650.

[6] E. Furimsky, Characterization of cokes from fluid/flexi-coking of heavy feeds, Fuel Process. Technol. Vol. 67 (2000) No. 2, p. 205-230.

[7] L.C. Castañeda, J.A.D. Muñoz, J. Ancheyta, Combined process schemes for upgrading of heavy petroleum. Fuel. Vol. 100 (2012) p. 110-27.

[8] Y. Zhang, D. Yu, W. Li, et al. Bifunctional catalyst for petroleum residue cracking gasification. Fuel. Vol. 117, Part B (2014) p. 1196-203.

[9] Y. Zhang, D. Yu, W. Li, et al. Fundamental study of cracking gasification process for comprehensive utilization of vacuum residue. Appl. Energy. Vol. 112 (2013) p. 1318-25.

[10] A.J. Kolombos, Olefins production by steam cracking over manganese catalyst, U.S. Patent 4,087,350. (1978).

[11]A. Corma, C. Martinez, L. Sauvanaud, New materials as FCC active matrix components for maximizing diesel (light cycle oil, LCO) and minimizing its aromatic content. Catal. Today. Vol. 127 (2007) No. 1-4, p. 3-16.

[12]N. Viriya-empikul, P. Krasae, W. Nualpaeng, et al. Biodiesel production over Ca-based solid catalysts derived from industrial wastes. Fuel. Vol. 92 (2012) No. 1, p. 239-44.

[13]Y.R. Xie, J. Xiao, L.H. Shen, et al. Effects of Ca-Based Catalysts on Biomass Gasification with Steam in a Circulating Spout-Fluid Bed Reactor. Energy Fuels. Vol. 24 (2010) p. 3256-61.

[14]C.S. Zhao, L.S. Lin, K.L. Pang, et al. Experimental study on catalytic steam gasification of natural coke in a fluidized bed. Fuel Process. Technol. Vol. 91 (2010) No. 8, p. 805-9. 